NBER WORKING PAPER SERIES

\author{
THE EFFECTS OF OUTBOUND \\ FOREIGN DIRECT INVESTMENT ON \\ THE DOMESTIC CAPITAL STOCK
}

Martin Feldstein

Working Paper No. 4668

\author{
NATIONAL BUREAU OF ECONOMIC RESEARCH \\ 1050 Massachusetts Avenue \\ Cambridge, MA 02138 \\ March 1994
}

This paper was prepared as part of the NBER project on the taxation of multinational corporations and was presented at the project conference on January 14, 1994. An earlier version was presented at the 1993 NBER Summer Institute. I am grateful to Joosung Jun for detailed discussions about measurement issues and data sources and to Todd Sinai for help with the regression analysis presented in sections 3 and 4. I benefitted also from comments on an earlier draft by Ken Froot, Jim Hines, Glenn Hubbard, Robert Lipsey and Joel Slemrod. This paper will be published in the NBER conference volume, The Effects of International Taxation on Multinational Corporations. This paper is part of NBER's research programs in International Trade and Investment and Public Economics. Any opinions expressed are those of the author and do not necessarily represent those of the National Bureau of Economic Research. 


\title{
THE EFFECTS OF OUTBOUND FOREIGN DIRECT INVESTMENT ON THE DOMESTIC CAPITAL STOCK
}

\begin{abstract}
This paper analyzes the effect of outbound foreign direct investment (FDD) on the domestic capital stock. The first part of the paper shows that only about 20 percent of the value of assets owned by U.S. affiliates abroad is financed by cross-border flows of capital from the United States. An additional 18 per cent represents retained earnings attributable to U.S. investors. The rest is financed locally by foreign debt and equity.

The second part of the paper analyzes data for the major industrial countries of the OECD and finds that each dollar of cross-border flow of foreign direct investment reduces domestic investment by approximately one dollar.

This dollar for dollar displacement of domestic investment by outbound FDI is consistent with the Feldstein-Horioka picture of segmented capital markets. It suggests that while portfolio funds are largely segmented into national capital markets, direct investment can achieve crossborder capital flows. A dollar outflow of direct investment reduces domestic investment by a dollar and this is not offset by a change in international portfolio investment. This ability of foreign direct investment to circumvent the segmented national capital markets also appears in the expanded use of foreign debt and equity capital to finance the capital accumulation of foreign affiliates of U.S. firms.

Taken together, these estimates suggest that each dollar of foreign assets acquired by U.S. foreign affiliates reduces the U.S. domestic capital stock by between 20 cents and 38 cents. Equivalently, this implies that each dollar of displaced domestic capital in the United States adds between $\$ 2.60$ and $\$ 5.00$ to the capital stock of U.S. foreign affiliates.

Martin Feldstein Harvard University and NBER 1050 Massachusetts Avenue Cambridge, MA 02138
\end{abstract}




\section{The Effects of Outbound Foreign Direct Investment on the Domestic Capital Stock}

Martin Feldstein

Foreign direct investment plays an important role in the international transfer of both capital and technology and has a significant impact on the pattern of international trade. The most recent detailed government survey of U.S. direct investment abroad found that in 1989 the foreign affiliates of U.S. multinational corporations had assets of more than $\$ 1.2$ trillion, approximately 25 percent of U.S. gross domestic product in that year.

Companies make direct investments abroad by acquiring existing business assets of foreign companies, by starting new businesses with "greenfield" investments in plant and equipment, and by increasing their investments in foreign businesses that they already own.

These foreign investments can be either wholly owned by the parent company or owned jointly with foreign partners. ${ }^{1}$

\footnotetext{
'The minimum extent of the parent company's ownership share required to make an investment qualify as "direct" rather than portfolio investment depends on the particular definition of foreign direct investment. The common balance of payments definition of foreign direct investment is based on ownership of at least 10 percent of the equity in the foreign business. For some purposes, it is more sensible to concentrate on businesses where the parent has a majority ownership interest.
} 
The heterogeneity of foreign direct investment reflects the diversity of motives for making such investments. ${ }^{2}$ At one extreme, some foreign direct investment (like the purchase of commercial real estate) is not fundamentally different from portfolio investment and the motivation is the standard desire to diversify portfolio assets. A more traditional motivation for FDI is to take advantage of low cost labor or proximity to raw materials. The primary reason is probably to maintain or increase foreign sales and market share. Thus, manufacturing companies that make products for industrial customers invest abroad in order to have closer working relations with customers, especially when their products must be specifically designed or modified for their customers. Many service companies must invest abroad if they want to provide services to those local markets. And some manufacturers acquire foreign firms in order to gain entry into local markets.

Government policies significantly influence the pattern of foreign direct investment, sometimes intentionally and sometimes inadvertently. Some governments require local investment (to create industrial jobs or achieve technology transfers) as a condition of access to government procurement or licensing. Other governments use favorable tax and credit policies to attract foreign investment. In contrast, some governments (e.g., Japan) are notorious for the regulatory barriers that deter inbound foreign direct investment.

The effects of government policies on FDI are not always intended, but may be the inadvertent by-products of policies designed to serve other purposes. Tariffs and other trade

${ }^{2}$ See Froot (1993) and Graham and Krugman (1989) and the references cited in those books for a general discussion of foreign direct investment with particular reference to the United States. 
barriers intended to protect domestic producers induce inbound foreign direct investment. The taxation of multinational companies can encourage or impede both inbound and outbound foreign direct investment.

There has been a substantial public policy debate about the effects of inbound and outbound foreign direct investment on the domestic economy. ${ }^{3}$ Much of the public concern is stated in terms of the effect of foreign direct investment on employment, with opponents of outbound FDI arguing that such FDI "takes production abroad" and reduces employment at home while proponents of outbound FDI counter that such FDI creates markets for U.S. exports to affiliates and through affiliates to foreign buyers. Economists recognize that this is a misplaced concern because the American labor market works well in assuring that all who want jobs at wages that reflect their skills can find work within a relatively short period of time. As Graham and Krugman emphasize: "The net impact of FDI on U.S. employment is approximately zero, and the truth of this assertion has nothing to do with job gains and losses at the industry level." (Graham and Krugman, 1989, p. 49; their italics). Studies that calculate the numbers of jobs "lost" because particular firms shift activity abroad (e.g., Bergsten et. al., 1978, and Hufbauer and Adler, 1968) do not take into account the absorption of those American workers by other firms and industries.

A related and more plausible concern is often expressed in terms of the impact of FDI on the "quality" of jobs. The worry is that although the forces of supply and demand maintain total employment, the shift of investment to foreign countries causes a substitution in the United

${ }^{3}$ See, for example, the discussions in Bergsten et. al. (1978), Graham and Krugman (1989) and Hufbauer and Adler (1968). 
States of low wage jobs for the higher wage manufacturing jobs that have gone abroad. As a general proposition, this is again incorrect. In a well-functioning labor market like ours, wages reflect the skills of the workers and are therefore not affected by the entry or exit of individual firms. There are some ways, however, in which foreign investment could affect wages. Market imperfections that permit workers in some industries to be paid substantially more than individuals with similar skills in other industries (e.g., union power or the monopoly power of firms that share their monopoly profits with employees) do provide a mechanism by which the mix of firms can affect the distribution of wages. In addition, even without such market imperfections, FDI can affect the quality of jobs if it alters the marginal product of labor. This can happen if FDI changes the domestic capital stock. It can also happen if FDI increases or decreases the kinds of jobs that are more likely to involve substantial on-the-job training. Training reflects the mix of industries and may be more important in capital intensive industries than in other industries. ${ }^{4}$

This leads naturally to two questions about the effect of FDI on the capital stocks of both the parent and host countries. First, what impact does an increase in the assets of foreign affiliates have on the parent country's capital stock? Second, what impact does an inflow of foreign direct investment have on the host country's capital stock? The answers to these questions may well depend on the form of the foreign direct investment and on the reason for

\footnotetext{
${ }^{4}$ For an extensive discussion of the impact of outbound foreign direct investment on employment in the United States, see Lipsey (1993). Lipsey concludes that the effect of increased outbound FDI on the domestic employment by multinational companies is probably slightly positive (as outbound FDI increases exports) and that the mix of domestic jobs shifts toward more higher paying technical and managerial positions.
} 
the particular inflow or outflow of such investment. ${ }^{5}$ Although the available data do not permit such a disaggregated analysis, it is possible to assess the extent to which countries that experience sustained high rates of inbound or outbound foreign direct investment have higher or lower levels of domestic investment than would otherwise be expected. The current study focuses on estimating the extent to which outbound foreign direct investment reduces domestic investment in the parent country.

Previous studies of this question have been microeconomic partial equilibrium analyses that have asked whether firms that invest more abroad reduce their investment at home. ${ }^{6}$ Although these studies can shed interesting light on the behavior of multinational companies, they do not indicate the net effect on the economy as a whole when individual firms increase their outbound FDI. When firms increase their overseas investment, the funds that they might otherwise have used in the United States might instead finance greater domestic investment by others, leaving both the aggregate capital outflow and the level of domestic investment unchanged. Alternatively, the process of outbound FDI might increase the aggregate net capital outflow and therefore reduce total domestic investment. Resolving the policy debate about the effect of FDI on domestic investment requires resolving this macroeconomic general equilibrium issue.

This paper presents information on the general equilibrium effect of foreign direct

\footnotetext{
SSince foreign direct investment is an endogenous variable in the complex system of trade and capital flows, it would in principle be desirable to estimate a more fully articulated structural model in which one can assess the extent to which changes in exogenous variables that alter FDI influence domestic investment through this route. I return to this issue in section 4 below.

${ }^{6}$ These studies include Blomstrom et al (1988), Lipsey and Weiss (1984), Severn (1972), Stevens (1969)
} 
investment based on aggregate evidence about investment flows in the OECD countries. The analysis focuses on the effect of outbound foreign direct investment and implies that such investment does reduce domestic investment but that each dollar of assets in foreign affiliates reduces the domestic capital stock by substantially less than a dollar. The best summary of the evidence is that each dollar of assets in foreign affiliates reduces the domestic capital stock by between 20 cents and 40 cents.

Before looking at the basis for these conclusions, it is useful to begin by considering several alternative concepts of foreign direct investment and the relevant magnitude of each for the United States. This is the subject of section one. The second section discusses alternative theories of how outbound foreign domestic investment could affect the domestic capital stock. Section 3 and 4 present investment equations that are estimated using the OECD data. The implications of this for the displacement question are discussed in the final section. Appendix A presents the basic data used in sections 3 and 4 .

\section{Three Concepts of Foreign Direct Investment}

Several alternative concepts of the stock of foreign direct investment are possible. A very narrow definition measures the stock of FDI as the accumulated cross-border flow of equity and debt from the parent company to its foreign subsidiary. The parent company may however have control over a much larger volume of foreign assets, including those financed by retained earnings and by borrowing from foreign and other domestic creditors.

This section starts with the narrowest definition of outbound FDI and then presents a series of building blocks that can be used to construct broader measures of foreign direct 
investment. For each building block, there is an estimate of the value from the point of view of U.S. parents as of the end of 1989.

To avoid the special problems of comparing bank assets and liabilities with those of other types of businesses, this analysis is limited to non-bank affiliates of non-bank U.S. corporate parents. Similarly, in order to focus on foreign investments in which the U.S. parent has an unambiguous controlling interest, the analysis is limited to majority owned non-bank affiliates of U.S. non-bank parents.

These calculations are based on data from the 1989 Benchmark Survey of U.S. Investment Abroad (U.S. Department of Commerce, 1992). Although the Benchmark Survey data report the current dollar values of the debts of foreign affiliates ${ }^{8}$, the value of assets and therefore the value of equity is stated only as historic cost values. The value of original equity investments and of retained earnings must therefore be adjusted for past price changes to calculate the corresponding current cost values.

In the absence of the necessary detail on annual investment flows, I have done so by using the historic cost and current cost values for the total equity of all U.S. foreign direct investment (not just majority owned nonbank affiliates of non-bank parents) that are published

${ }^{7}$ The restrictions to nonbank firms and to those with majority ownership by the U.S. parent together reduce the measured stock of U.S. owned FDI (according to the balance of payments measure) by approximately 18 percent. All U.S. foreign direct investment had a value (according to the balance of payments measure) in 1989 of $\$ 553$ billion while the corresponding figure for majority-owned nonbank affiliates was $\$ 452$ billion. Both figures are estimates of current (1989 dollar) cost values.

${ }^{8}$ The foreign debt is translated into U.S. dollars at current exchange rates but is not adjusted for changes in value due to changed in interest rates since the debt was issued. 
by the Department of Commerce. At yearend 1989, the total value of all U.S. foreign direct investment abroad ${ }^{9}$ was $\$ 553$ billion at current cost (1989 dollars) and $\$ 370$ billion at historic cost (Survey of Current Business, 1992). Since the debt component of this balance of payments measure of the stock of foreign direct investment was $\$ 24$ billion, the corresponding equity amounts were $\$ 529$ billion at current cost and $\$ 346$ billion at historic cost, a ratio of 1.53 . Despite the obvious limitations of using a single ratio for both initial equity investments and subsequent retained earnings, this ratio will be used to adjust all historic cost equity values in the 1989 Benchmark Survey to the corresponding current cost estimates.

I turn now to an analysis of the different concepts of the foreign direct investment in the nonbank affiliates of nonbank U.S. parents. The narrowest definition of foreign direct investment is the net external finance from the U.S, parent to the foreign affiliate. This external finance at yearend 1989 consisted of $\$ 202$ billion of initial equity investments of U.S. parents (at current cost) ${ }^{10}$ and $\$ 25$ billion of net debt provided by those same parents. ${ }^{11}$

1. Net External finance from U.S. parents

la Equity from U.S. Parents

1b Net Debt from U.S. Parents
$\$ 227$ billion

(\$202 billion)

$(\$ 25$ billion)

9 This is the "balance of payments" measure of foreign direct investment. It is the sum of the initial equity investments of U.S. parents, the subsequent retained earnings and any net debt from U.S. parents to their foreign affiliates.

${ }^{10}$ The historic cost number reported in the 1989 Benchmark Survey (Table III.C.1) is $\$ 132$ billion. Multiplying this by the factor 1.53 produces the current cost estimate of $\$ 202$ billion.

"1 The gross debt from U.S. parents to their foreign affiliates was $\$ 84$ billion. This was offset in large part by $\$ 59$ billion of credit from affiliates to parents, leaving a net debt of affiliates to parents of $\$ 25$ billion. The balance of payments measure of foreign direct investment includes only the net debt and I follow that procedure in the current analysis. 
A small amount of additional equity investment and credit is extended to these overseas affiliates by other U.S. investors and creditors. The equity invested in majority owned businesses by American companies other than the parent company is very small, only a cumulative $\$ 1$ billion. American creditors other than the parent firm provided credit of $\$ 22$ billion. ${ }^{12}$

\section{External finance from other U.S. sources}

2a Equity from other U.S. investors

$2 b$ Debt from other U.S. sources

\section{\$ 23 billion}

(\$ 1 billion)

( $\$ 22$ billion)

The external finance from U.S. sources is substantially augmented by equity and debt from foreign sources. Even among these affiliates that are majority owned by their U.S. parents, foreign sources invested equity of $\$ 92$ billion at current $\operatorname{cost}^{13}$ and foreign creditors provided $\$ 567$ billion $^{14}$.

3. External finance from foreign sources

3a Equity from foreign sources

3b Debt from foreign sources
$\$ 659$ billion

( $\$ 92$ billion)

( $\$ 567$ billion)

${ }^{12}$ The credit from the U.S. parent as well as from other U.S. sources includes trade credit as well as other forms of credit.

${ }^{13}$ This current dollar figure is based on the historic cost value of $\$ 60$ billion.

14 The 1989 Benchmark Survey reports that the total liabilities of the majority-owned nonbank affiliates of nonbank U.S. parents was $\$ 673$ billion. This included current liability and long-term debt of $\$ 562$ billion and "Other liabilities" (including deferred taxes of the subsidiary) of $\$ 111$ billion. Subtracting the $\$ 106$ billion of gross debt provided by U.S. parents and other U.S. sources (i.e., the sum of $\$ 25$ billion of net debt from parents, $\$ 59$ billion of offsetting debt from affiliates to parents that is counted as part of the gross debt of the affiliates, and $\$ 22$ billion of debt from other U.S. sources) leaves a balance of $\$ 567$ billion of debt supplied by foreign sources. 
The final source of capital in the foreign affiliates is the retained earnings that were reinvested after paying dividends to parents and others. The 1989 current cost estimate for the accumulated value of these retained earnings was $\$ 328$ billion. Dividing this aggregate among the three classes of investors in proportion to their historic cost values of retained earnings implies:

\section{Retained earnings}

4a Share of U.S. parents

$4 \mathrm{~b}$ Share of other U.S. investors

$4 c$ Share of foreign equity investors
$\$ 328$ billion

( $\$ 225$ billion)

(\$ 1 billion)

(\$102 billion)

With these building blocks, it is possible to define three progressively broader concepts of outbound foreign direct investment. The first is the Net External Finance from U.S. Sources. This is the sum of 1 and 2 above or $\$ 250$ billion.

The second measure of U.S. foreign direct investment adds the value of the retained earnings of foreign affiliates attributable to U.S. investors (the sum of $4 a$ and $4 b$ or $\$ 226$ billion) to the net external finance from U.S. parents and other U.S. sources. This Net Finance from U.S. Sources $^{15}$ had a value of $\$ 476$ billion.

The third natural definition is the value of the assets in the foreign affiliate, regardless of who finances those assets and of whether the finance is by debt or equity. This definition, the Value of Assets of U.S. Foreign Affiliates, is the sum of the four building blocks or $\$ 1,237$ billion.

The three concepts and the associated magnitudes are shown in Table 1.

\footnotetext{
${ }^{15}$ This exceeds the Official Balance of Payments definition of the stock of U.S. foreign investment by including the value of the equity and debt of U.S. investors and creditors who are not parents of the foreign affiliates.
} 
2. The Displacement Effect of Outbound Direct Investment: Partial Equilibrium vs. General Equilibrium Analysis

How does the decision of an American firm to invest abroad in a foreign subsidiary affect the total amount of investment in the United States? Despite the widespread interest in this question, there has been no formal analysis or empirical investigation of the general equilibrium effect of outbound FDI on domestic investment.

\subsection{The Behavior of Individual Firms}

The common popular discussion of this issue treats it as a partial equilibrium question of where corporate production will occur. As noted above, opponents of outbound FDI argue that such investment reduces domestic production by substituting for exports while defenders of outbound FDI argue that overseas subsidiaries increase the market for U.S. exports and therefore increase production in the United States. There are undoubtedly examples of both possibilities in actual practice. These countervailing effects may explain why the very careful study of individual multinational firms by Stevens and Lipsey (1988) failed to find any significant effects of overseas production on domestic exports and investment. ${ }^{16}$

An alternative partial equilibrium analysis would start with the corporate financial decisions and ask whether a firm that invests more abroad will invest less at home. In the simplest textbook version of the investment decision, the firm can borrow as much as it wants at a fixed interest rate and therefore invests until the marginal product of capital equals that rate

${ }^{16}$ Similar evidence that outbound FDI is not associated with export displacement is reported in Blomstrom et. al. (1988) and in Lipsey and Weiss $(1981,1984)$. 


\section{Table 1}

\section{Alternative Measures of Foreign Direct Investment}

\section{Concept of Foreign Direct Investment}

1. Net External Finance from U.S. Sources $(1+2)$

2. Net Finance from U.S. Sources

$$
(1+2+4 a+4 b)
$$

3. Value of Assets of U.S. Foreign Affiliates

$$
(1+2+3+4)
$$

All values are adjusted to current cost in 1989 dollars.
Value at Year End 1989

$\$ 250$ billion

$\$ 476$ billion

$\$ 1237$ billion 
of interest. In such an economy, borrowing to finance overseas investment does not alter the furm's funds available for domestic investment.

Actual corporate experience is very far from these textbook models. The following simplified version of corporate capital budgeting shows how a firm's decision to invest abroad could reduce its domestic investment. In this view, the company starts with a fixed amount of after tax profits and a dividend payout that its shareholders expect. There is some but very little room to vary dividends from the expected amount. The combination of the retained earnings (after this dividend payout) and the company's desired debt to capital ratio determines the amount that the company can borrow and therefore the firm's total funds available for capital investments. ${ }^{17}$ Since this capital budget calculation is done for the multinational corporation as a whole rather than for individual subsidiaries, the result is a capital budget for the entire corporation. Any use of that capital abroad reduces the amount of capital available for domestic investment within the firm. ${ }^{18}$

However, as the analysis of section 1 indicated, much of the capital invested in U.S. affiliates overseas is raised abroad. It is clear that the share of foreign-source debt and equity in the U.S. foreign affiliates is far greater than the share of such foreign-source debt and equity in the financing of the domestic U.S. industry. This reflects the fact that most American firms

${ }^{17}$ The company could of course modify this by new equity issues, share repurchases, and divestitures but these should be seen as unusual events rather than as part of the annual capital budgeting process.

${ }^{18}$ Stevens and Lipsey (1988) investigate the financial interdependence between foreign investment and domestic investment over time in a sample of U.S. multinational firms and find that overseas investment does reduce domestic investment through this channel. Their formal model lies between the two extremes described in the current text: firms do not have a fixed debt-to-capital ratio but the cost of funds is a function of that ratio. 
are more likely to borrow abroad to finance overseas assets than to finance domestic assets. The reason for this is unclear. It may reflect a desire to hedge foreign currency profits with foreign currency debt, an ability to borrow more cheaply when collateral is available, or other aspects of the risk and return of financing behavior. This segmentation of borrowing may be a form of suboptimal behavior similar to the widely observed failure of portfolio managers to diversify investment.

Similarly, American firms are more likely to seek foreign joint venture partners for overseas subsidiaries (in order to get market access or other benefits of having a local partner) than they are to seek such equity investors here in the United States. The foreign equity investor is also likely to regard such direct investment as a joint venture partner within its own country as less risky than investing in the United States.

In short, even if outbound FDI substitutes for other investments within the firm's capital budget, more of the funds to finance that outbound FDI are likely to come from foreign sources than would be the case for domestic investment.

\subsection{Macroeconomic General Equilibrium Effects}

To assess the net impact of outbound FDI on total investment in the United States it is important to look beyond the partial equilibrium analysis of individual firms. The net impact of outbound FDI depends on the extent to which that outbound FDI changes the aggregate net outflow of capital from the United States, including net portfolio investment as well as net direct investment.

In a world of perfect capital mobility in which the total pool of world savings moves to finance those investments with the highest risk-adjusted rates of return, an increase in U.S. 
direct investment abroad need not have any effect on the U.S. capital stock. Funds would automatically flow in to finance domestic U.S. investments that eam the required rate of return.

But although the integration of global capital markets appears to be increasing, we are still a long way from the textbook model of perfect capital market integration. Gross international capital flows are large, but sustained net flows are relatively small. As Charles Horioka and I showed nearly 15 years ago (Feldstein and Horioka, 1980), a nation's savings tend to be invested in the country where they originate. ${ }^{19}$ The "saving retention coefficient" (the fraction of a marginal dollar of saving that is invested domestically) is estimated to be between 0.8 and 0.9 on average for the OECD countries. This is dramatically different from the world of perfect capital mobility in which a nation's rate of investment would not depend on its saving rate and therefore in which the saving retention coefficient would be zero.

Paradoxically, the extreme no-net-capital-flow case (a saving retention coefficient of 1.0 that is uninfluenced by the volume of outbound or inbound FDI) has the same implication in the current context as the perfect capital mobility case: an outflow of direct investment does not change the amount of net domestic investment. Any net outflow of FDI in this case would be offset by a reduction in outbound portfolio investment or an increase in inbound portfolio investment. The previous estimates of the Feldstein-Horioka type investment-saving equations did not explicitly test whether the amount of domestic investment is influenced by the outbound or inbound FDI. That is the subject of the next two sections.

19 This fact has since been replicated many times. See Frankel (1992) and Mussa and Goldstein (1993) for discussions of this literature and comments on the reasons why savings remain at home even in a world capital market that appears to be quite closely linked and very active. See also Baxter and Crucini (1993) and Feldstein and Bacchetta (1991). 
A more likely possibility is that the Feldstein-Horioka relation relates to portfolio investment rather than to direct investment. In the extreme case, an extra dollar of national saving would remain in domestic portfolio assets unless it is used by a multinational corporation to finance a cross-border direct investment. Such an outbound FDI would reduce the funds available for domestic investment by an equal amount, as the above corporate budget example suggests. If the portfolio investments were completely segmented into national markets in this way, the effect of the outbound FDI on domestically available funds would not be offset by any international flow of portfolio capital and the aggregate domestic investment would be reduced by the full amount of the direct investment outflow.

The evidence in the next two sections support the idea that foreign direct investment transfers capital across borders with very little offsetting net portfolio investment. More specifically, the evidence indicates that each dollar of outbound FDI reduces domestic investment by approximately one dollar.

\section{Estimates of the Effects of FDI on Domestic Investment}

The estimates presented in this section are an extension of earlier work reported in a number of papers beginning with Feldstein and Horioka (1980). ${ }^{20}$ The basic Feldstein-Horioka specification relates the ratio of gross domestic investment to GDP to the ratio of gross national saving to GDP. Since these ratios are calculated as decade averages, the analysis relates to sustained differences among countries rather than year to year changes. The specification assumes that the national differences in saving determine national differences in investment

\footnotetext{
${ }^{20}$ See Frankel (1992) and Mussa and Goldstein (1993) for summaries of this literature.
} 
rather than the reverse. Since these specification issues have been discussed extensively in previous articles ${ }^{21}$, I will not comment on them here.

The innovation in the current study is to add data on inbound and outbound FDI to the previous bivariate specification. The simplest form of the resulting equation is:

$$
\text { GDI/GDP }=a+b[\text { GNS/GDP] }+c[\text { (FDI-out)/GDP] }+d[(\text { FDI-in) } / \text { GDP }]+u
$$

where GDI is gross domestic investment, GNS is gross national saving, GDP is gross domestic product, the two types of FDI are denoted FDI-out and FDI-in, and $u$ is a stochastic disturbance. The individual variables in the numerator and denominator of each ratio are flows at annual rates denominated in current dollars in national currencies. The ratios are decade averages of annual ratios for each country. More general specifications with additional variables are discussed in section 4 .

By definition, GDI includes only the investment done within the geographic boundaries of the home country. Investment by foreign affiliates of the home country's multinationals are excluded. Investment within the geographic boundaries of the home country that is done by the local affiliates of foreign multinationals is included in GDI. The GNS figures include the saving in the form of retained earnings of foreign affiliates of the home country's multinationals. The foreign direct investment values are based on the balance of payments definition and refer to all foreign affiliates, not just majority owned or nonbank affiliates. These data are not ideal but they are the best data available for this study.

Although the OECD produces consistent data on GDI, GNS and GDP, there are no

\footnotetext{
${ }^{21}$ See Feldstein (1983) and Feldstein and Bachetta (1991) as well as the references cited in the previous footnote.
} 
yofficial OECD data on FDI. The data on FDI come from the International Monetary Fund ${ }^{2}$. The limited availability of data on FDI restricts the sample to 18 of the 24 OECD countries for the decade of the 1980s and 15 of those countries for the decade of the 1970s. This section presents separate results for both samples as well as for a pooled sample of 33 observations. For all of these countries it is possible to obtain estimates of FDI excluding retained earnings (RE). It is also possible to obtain the amount of retained earnings of these foreign affiliates for nine of the countries during the decade of the 1970 s and ten of the countries during the decade of the 1980s. Estimates are also presented for these smaller samples.

The first three equations presented in Table 2 are the standard investment-savings relation without FDI. The estimated savings retention coefficients for this sample of OECD countries are 0.87 (s.e. $=0.10$ ) for the 1970 s and $0.74($ s.e. $=0.12)$ for the 1980 s, very similar to the estimates obtained with the larger samples of OECD countries in past research. The savings retention coefficient for the pooled data is $0.80($ s.e. $=0.07)$ and lies between the two individual decade estimates.

In equation 4 of Table 2, the coefficient of the FDI-out variable is $-1.73($ s.e. $=0.90$ ) and the coefficient of the FDI-in variable is $0.80($ s.e. $=1.11)$. Adding these two FDI variables to the traditional saving-investment equation leaves the estimated savings retention coefficient virtually unchanged at 0.84 (s.e. $=0.10$ ).

The coefficient of the FDI-out variable which is of primary interest in the current analysis is quite stable in the different time periods and specifications. It is always negative, implying

${ }^{n}$ These data are published in the Balance of Payments Yearbook. The current study uses updated unpublished data. The actual data are presented in the Appendix to this paper. 
that the aggregate level of domestic investment in a country declines when outbound FDI increases. Since this effect is conditional on given levels of national saving and inbound FDI, it implies that other international capital flows (inbound and outbound portfolio investment and borrowing) do not adjust to offset the direct effect of outbound FDI on domestic investment. The coefficient of outbound FDI is $-1.73($ s.e. $=0.62)$ in the 1970 s and $-1.65($ s.e. $=0.69)$ in the 1980 s when FDI is defined as a cross-border capital transfer (i.e., excluding retained earnings of the foreign affiliates). Adding the retained earnings of foreign

affiliates (equation 7) leaves the coefficient for 1970 essentially unchanged ( -1.42 with s.e. $=$ 0.40 ) and increases the absolute size of the 1980 coefficient only slightly $(-1.87$ with s.e. $=0.63)$.

It would of course be desirable to distinguish the response of domestic investment to outbound cross-border FDI flows from the response of domestic investment to the retained earnings of the foreign affiliates. Unfortunately, there are too few observations to make such an estimate. Attempts to use the samples corresponding to equations 7 through 9 to look at the retained earnings variable separately (in addition to the other variables already in those equations) results in almost no residual degrees of freedom and therefore to very unstable coefficient estimates with very large standard errors. It is not possible to determine statistically whether a one dollar increase in GNS due to an increase in the RE of foreign affiliates has the same impact on GDI as a one dollar rise in GNS due to domestic savings. ${ }^{23}$ Similarly, when outbound FDI is defined to include the retained earnings of foreign affiliates (equations 7 through 9) it is not clear whether the reaction to the cross-border FDI flow is the same as the

\footnotetext{
${ }^{23}$ Recall that gross national saving includes the retained earnings of foreign affiliates.
} 
Table 2

Effects of National Saving and FDI on Domestic Investment

\begin{tabular}{|c|c|c|c|c|c|c|c|}
\hline Equat. & Period RE & $\mathbf{N}$ & Const. & GNS & FDI-Out & FDI-In & Adj. $R^{2}$ \\
\hline 1 & $1970 \mathrm{~s}$ & 15 & $\begin{array}{l}0.04 \\
(0.02)\end{array}$ & $\begin{array}{c}0.87 \\
(0.10)\end{array}$ & & & 0.85 \\
\hline 2 & $1980 \mathrm{~s}$ & 18 & $\begin{array}{l}0.07 \\
(0.03)\end{array}$ & $\begin{array}{l}0.74 \\
(0.12)\end{array}$ & & & 0.67 \\
\hline 3 & Pooled - & 33 & $\begin{array}{l}0.05 \\
(0.02)\end{array}$ & $\begin{array}{l}0.80 \\
(0.07)\end{array}$ & & & 0.79 \\
\hline 4 & 1970s No & 15 & $\begin{array}{l}0.05 \\
(0.03)\end{array}$ & $\begin{array}{l}0.84 \\
(0.10)\end{array}$ & $\begin{array}{l}-1.73 \\
(0.90)\end{array}$ & $\begin{array}{l}0.80 \\
(1.11)\end{array}$ & 0.87 \\
\hline 5 & 1980s No & 18 & $\begin{array}{l}0.08 \\
(0.03)\end{array}$ & $\begin{array}{l}0.74 \\
(0.12)\end{array}$ & $\begin{array}{l}-1.65 \\
(0.69)\end{array}$ & $\begin{array}{l}0.47 \\
(0.86)\end{array}$ & 0.74 \\
\hline 6 & Pooled No & 33 & $\begin{array}{l}0.07 \\
(0.02)\end{array}$ & $\begin{array}{l}0.77 \\
(0.07)\end{array}$ & $\begin{array}{l}-1.58 \\
(0.47)\end{array}$ & $\begin{array}{l}0.59 \\
(0.62)\end{array}$ & 0.84 \\
\hline 7 & 1970s Yes & 9 & $\begin{array}{l}0.06 \\
(0.03)\end{array}$ & $\begin{array}{l}0.76 \\
(0.12)\end{array}$ & $\begin{array}{l}-1.42 \\
(0.46)\end{array}$ & $\begin{array}{l}2.18 \\
(0.63)\end{array}$ & 0.90 \\
\hline 8 & 1980s Yes & 10 & $\begin{array}{l}0.10 \\
(0.05)\end{array}$ & $\begin{array}{l}0.59 \\
(0.23)\end{array}$ & $\begin{array}{l}-1.87 \\
(0.63)\end{array}$ & $\begin{array}{l}2.51 \\
(1.09)\end{array}$ & 0.67 \\
\hline 9 & Pooled Yes & 19 & $\begin{array}{l}0.08 \\
(0.03)\end{array}$ & $\begin{array}{l}0.66 \\
(0.11)\end{array}$ & $\begin{array}{l}-1.71 \\
(0.37)\end{array}$ & $\begin{array}{l}2.38 \\
(0.59)\end{array}$ & 0.82 \\
\hline
\end{tabular}

The column marked RE indicates whether the FDI variables include or exclude the retained earnings of the foreign affiliates. 
reaction to FDI-out that is achieved without a cross-border flow by an increase in the retained earnings of the affiliate.

The reaction of domestic home country investment to a dollar of dividends that is repatriated by the subsidiary to the parent company is ambiguous a priori as well. Although the direct effect of the dividend repatriation would be to add to the domestic capital stock, this could be offset to the extent that the dividend induces a reduction in inbound portfolio investment or an increase in outbound direct or portfolio investment. Since the econometric evidence cannot resolve this ambiguity, section 5 examines the implications of the two alternative extreme assumptions that subsidiary retained earnings reduce domestic (home country) investment dollarfor-dollar and, alternatively, that they do not affect domestic investment at all.

\section{Additional Variables and Simultaneity Problems}

The interpretation of the coefficients in Table 2 is clouded by the fact that the saving rate and the two FDI ratios are endogenous variables in the overall economic system. In particular, the levels of inbound and outbound FDI are likely to be correlated with variables that favor higher domestic rates of investment. A country that offers a "good environment" for domestic investment is also likely to attract more inbound FDI and may also experience less outbound FDI. This section shows that this problem of missing variables does indeed bias the coefficients shown in section 3, increasing the absolute size of both the FDI-out and FDI-in coefficients.

The results in this section are thus quite different from the earlier studies of potential bias in the estimated savings retention coefficient in the simpler Feldstein-Horioka specification. Since it is certainly possible that some of the same factors that cause a country to have a higher 
saving rate might also cause it to have a higher investment rate, Feldstein and Bacchetta (1991) also estimated the basic specification by an instrumental variable estimation procedure using demographic characteristics and social security variables as instruments for the national saving rate. Although the relatively small sample of fewer than two dozen countries limits the relevance of the consistency property of IV estimation, the similarity of the OLS and IV estimates provides some reassurance that the potential endogeneity of the savings rate is not a source of significant bias. Further support for the assumption that long-term intercountry differences in saving cause long-term differences in investment (rather than the reverse or a simultaneous equations relation) is obtained by dividing national saving into private saving and government saving and noting that both components of national saving have essentially the same effect on domestic investment in a generalized Feldstein-Horioka specification (Feldstein and Bacchetta, 1991).

Although it would be desirable to re-estimate the equations in Table 2 using an instrumental variable approach, I have been unable to find any variables that would be satisfactory instruments. I decided therefore to pursue a different approach to reducing the possible bias in the estimated FDI coefficients by expanding the specification of the investment equation to include additional determinants of investment that might also be correlated with either or both of the FDI variables. Although some bias might remain even in this specification because not all possible variables are included, this method is preferable to using an instrumental variable estimation procedure with a very small sample and very inadequate instruments.

Table 3 summarizes the results of these more general specifications. The evidence confirms that outbound FDI does reduce domestic investment but the coefficients are now 
absolutely smaller, indicating that the previously omitted variables were common factors that affected FDI-out and GDI in similar ways. ${ }^{24}$

For example, equation 1 of Table 3 (which is estimated for the pooled sample of 33 country-decade observations) includes four variables in addition to the saving rate and FDI variables: (1) a dummy variable indicating whether the country is in Europe (E); (2) the size of the country as measured by its average population during the decade (SIZE); (3) the average inflation rate during the decade (INF); and (4) the average growth rate of GDP during the decade (GRO). These variables are listed as "Other Variables" in the description of equation 1. Those "other variables" with a t-statistic between 1 and 2 are marked with an asterisk while those with a t-statistic in excess of two are marked with two asterisks. Thus E, SIZE and INF have t-statistics greater than 2 while GRO is not statistically significant. In this specification, the coefficient of FDI-out is -1.17 with a standard error of 0.47 .

Equation 2 adds the average short-term interest rate (INT) and deletes the insignificant growth variable. This specification, which has the highest adjusted $R^{2}$ of all the variable combinations that I have examined, also suggests that the coefficient of FDI-out is approximately minus one, i.e., that each dollar of FDI-out reduces GDI by about one dollar.

The next four equations in Table 3 are for the individual decades. The absolute values of the coefficient of FDI-out are slightly smaller than one in each of these specifications. The large standard errors in these equations should be interpreted in the context of the smaller

\footnotetext{
${ }^{24}$ The coefficients of FDI-in change even more substantially and are now insignificant in every case, indicating that the inflow of FDI does not appear to alter the domestic investment rate. Presumably the capital inflow in the form of inbound FDI substitutes for inbound portfolio investment or induces other balancing transactions.
} 
samples for individual decades (only 15 observations for the 1970 s and 18 observations for the 1980s) which, together with the additional variables, leaves as few as 7 residual degrees of freedom. But taken together with the pooled data of equations 1 and 2 and the separate decade estimates for the simpler specifications in Table 2, it seems most appropriate to conclude that each dollar of cross-border FDI-out reduces domestic investment by approximately one dollar.

The FDI variables reported in equations 1 through 6 of Table 3 all measure FDI excluding retained eamings. Although eliminating the eight countries that do not provide information on retained earnings would leave too small a sample of observations for either decade alone, it is possible to use the pooled sample of 19 observations for the two decades.

The results are shown in equations 7,8 and 9 . The first two of these repeat the two specifications of equations 1 through 6 while equation 9 is the specification with the highest adjusted $R^{2}$ when the FDI variables are defined to include retained earnings.

The coefficients are similar in all three specifications. The estimated effect of FDI-out is slightly larger in absolute size than in the pooled estimates of equations 1 and 2 but, given the small sample and large standard errors, is not significantly different from -1.0. The major difference from the other equations in Table 3 is that the coefficient of the FDI-in variable rises to approximately 1.0 and becomes nearly twice its standard error. This implies that the retained earnings of foreign affiliates in a given host country, like other forms of domestic saving in that country, increases domestic investment in that host country. 
Table 3

Impact of Additional Variables on the Estimated Effect

of Foreign Direct Investment on Domestic Investment

\begin{tabular}{|c|c|c|c|c|c|c|}
\hline Equat. & $\begin{array}{l}\text { Period } \\
\text { N; RE }\end{array}$ & GNS & FDI-out & FDI-in & Other Variables & Adj. $R^{2}$ \\
\hline 1. & $\begin{array}{l}\text { Pooled } \\
\text { 33; No }\end{array}$ & $\begin{array}{l}0.76 \\
(0.07)\end{array}$ & $\begin{array}{l}-1.17 \\
(0.47)\end{array}$ & $\begin{array}{l}0.16 \\
(0.50)\end{array}$ & $\begin{array}{l}\mathrm{E}^{* *}, \mathrm{SIZE}^{* *}, \mathrm{INF}^{* *} \\
\text { GRO }\end{array}$ & 0.90 \\
\hline 2. & $\begin{array}{l}\text { Pooled } \\
\text { 33; No }\end{array}$ & $\begin{array}{l}0.79 \\
(0.05)\end{array}$ & $\begin{array}{l}-1.10 \\
(0.40)\end{array}$ & $\begin{array}{l}-0.04 \\
(0.44)\end{array}$ & $\begin{array}{l}\mathrm{E}^{* *}, \mathrm{SIZE}^{* *}, \mathrm{INF}^{*} \\
\text { INT** }\end{array}$ & 0.92 \\
\hline 3. & $\begin{array}{l}1970 \text { s } \\
15 ; \text { No }\end{array}$ & $\begin{array}{l}0.85 \\
(0.17)\end{array}$ & $\begin{array}{l}-0.92 \\
(0.91)\end{array}$ & $\begin{array}{l}-0.03 \\
(1.21)\end{array}$ & $\begin{array}{l}\text { E, SIZE*, INF* } \\
\text { GRO }\end{array}$ & 0.89 \\
\hline 4. & $\begin{array}{l}1970 \text { s } \\
15 ; \text { No }\end{array}$ & $\begin{array}{l}0.87 \\
(0.11)\end{array}$ & $\begin{array}{l}-0.83 \\
(1.04)\end{array}$ & $\begin{array}{l}0.00 \\
(1.16)\end{array}$ & $\begin{array}{l}\text { E, SIZE*, INF0. } \\
\text { INT }\end{array}$ & 89 \\
\hline 5. & $\begin{array}{l}1980 \text { s } \\
18 ; \text { No }\end{array}$ & $\begin{array}{l}0.65 \\
(0.09)\end{array}$ & $\begin{array}{l}-0.80 \\
(0.55)\end{array}$ & $\begin{array}{l}-0.19 \\
(0.57)\end{array}$ & $\begin{array}{l}\mathrm{E}^{* *}, \mathrm{SIZE}^{* *}, \mathrm{INF}^{* *} \\
\text { GRO }\end{array}$ & 0.91 \\
\hline 6. & $\begin{array}{l}\text { 1980s } \\
18: \text { No }\end{array}$ & $\begin{array}{l}0.65 \\
(0.10)\end{array}$ & $\begin{array}{l}-0.81 \\
(0.54)\end{array}$ & $\begin{array}{l}-0.20 \\
(0.54)\end{array}$ & $\begin{array}{l}E^{* *}, S^{\prime 2 E} * *, I^{*} \\
\text { INT }\end{array}$ & 0.91 \\
\hline 7. & $\begin{array}{l}\text { Pooled } \\
\text { 19; Yes }\end{array}$ & $\begin{array}{l}0.49 \\
(0.14)\end{array}$ & $\begin{array}{l}-1.59 \\
(0.42)\end{array}$ & $\begin{array}{l}1.41 \\
(0.58)\end{array}$ & $\begin{array}{l}\text { E, S1ZE**, INF } \\
\text { GRO }\end{array}$ & 0.89 \\
\hline 8. & $\begin{array}{l}\text { Pooled } \\
\text { 19; Yes }\end{array}$ & $\begin{array}{l}0.62 \\
(0.11)\end{array}$ & $\begin{array}{l}-1.36 \\
(0.38)\end{array}$ & $\begin{array}{l}0.94 \\
(0.54)\end{array}$ & $\begin{array}{l}E^{*}, \text { SIZE**, INF } \\
\text { INT* }\end{array}$ & 0.92 \\
\hline 9. & $\begin{array}{l}\text { Pooled } \\
19 ; \text { Yes }\end{array}$ & $\begin{array}{l}0.55 \\
(0.11)\end{array}$ & $\begin{array}{l}-1.37 \\
(0.31)\end{array}$ & $\begin{array}{l}0.92 \\
(0.49)\end{array}$ & $E^{*}, S_{2 Z E^{* *}, I^{*} T^{* *}}$ & 0.93 \\
\hline
\end{tabular}

Each equation also contains a constant term. The FDI-in and FDI-out variables exclude retained earnings in equations 1 through 6 and includes retained earnings in equations 7 through 9 . See text for definitions of "Other Variables." 
More generally, the evidence in this section implies that outflows of foreign direct investment reduce domestic investment on a dollar-for-dollar basis and that this reduction is not offset by an international shift in portfolio investment. This is consistent with a view that the Feldstein-Horioka segmentation of capital markets applies to portfolio investment and that direct investment circumvents this barrier to capital mobility. Similarly, foreign direct investment induces U.S. firms to use much more foreign debt and equity finance in their majority owned foreign affiliates than they would use for domestic investments. In that way, the financing of FDI also makes available the advantages of foreign portfolio financing in a way that would not occur without the direct investment.

\section{The Effect of Outbound FDI on Foreign Assets and the Domestic Capital Stock}

By combining the parameter estimates of sections 3 and 4 with the evidence on the sources of capital of foreign affiliates of U.S. multinationals in section 2 it is possible to answer the fundamental question of how much the U.S. domestic capital stock declines per dollar of additional capital in the foreign affiliates of U.S. multinationals.

The answer to this question depends on how that foreign affiliate capital is financed. The parameter estimates of sections 3 and 4 imply that on average within the OECD each dollar of cross-border external finance reduces domestic investment by one dollar.

The data analyzed in section 2 show that approximately 20 cents of each dollar of the existing U.S. foreign affiliate capital is financed by such a cross-border flow of capital from the United States. Of the remainder, 18 cents comes from the U.S. share of retained earnings of the foreign affiliate and 62 cents comes from foreign debt and equity sources. 
Before considering the implication of this average financing mix, I will consider two simpler cases:

\section{Pure Parent Finance}

Consider first the simplest case in which the incremental foreign affiliate capital is financed exclusively by the U.S. parent with no foreign equity or debt. If the U.S. general equilibrium response to cross-border capital outflows is similar to the average OECD response, each dollar of parent-to-affiliate finance reduces the U.S. domestic capital stock by one dollar. In this extreme case, each dollar of increased capital in the foreign affiliate reduces the U.S. domestic capital stock by one dollar.

\section{Leveraged Retained Earnings Finance}

As a second and much more common case, consider the foreign affiliate that uses retained earnings to finance an incremental investment and that combines those foreign retained earnings with local debt. The sources of financing per unit of incremental capital in the subsidiary can be defined as:

s - the retained earnings of the subsidiary attributable to the U.S. parent and other U.S. equity investors

$\mathrm{s}^{*} \quad$ - the retained earnings of the subsidiary attributable to non-U.S. sources

b* - the debt supplied by non-U.S. creditors

By assumption, in this case $s+s^{*}+b^{*}=1$.

The alternative to investing the retained earnings of the subsidiary would be to distribute 
them as dividends to the U.S. and foreign equity owners. The econometric analysis of sections 3 and 4 was not able to measure the average OECD response to changes in retained earnings or dividend repatriations. The effect on domestic capital formation in the home country of the subsidiary's choice between retaining earnings and repatriating those earnings as dividends cannot be settled by a priori analysis either. Consider therefore the alternative possibilities. If a dollar of repatriated dividends would add one dollar to the U.S. gross domestic investment, an additional dollar of foreign affiliate capital financed with leveraged retained earnings reduces the U.S. capital stock by $s<1$ dollars. To the extent that the repatriation of retained earnings displaces other financial capital inflows or increase financial capital outflows, the depressing effect on the U.S. capital stock would be smaller than s.

The analysis of section 1 shows that the retained eamings attributable to U.S. investors (corresponding to $s$ in the current calculation) were $\$ 226$ billion in 1989 , that the retained earnings attributable to foreign investors was $\$ 102$ billion, and that the debt from foreign sources was $\$ 567$ billion. If the relative magnitudes of these three financing sources are used to approximate the financing of the leveraged retained earnings investment, we obtain $s=226 / 895$ $=0.25$. With these assumptions, an additional dollar of foreign affiliate capital financed with leveraged retained earnings reduces the U.S. capital stock by 25 cents. This is an upper limit of the plausible range because it is based on the assumption that any retained earnings that are not invested by the foreign subsidiary would otherwise add dollar-for-dollar to the U.S. capital stock. 


\section{Average Financing}

The observed aggregate financing mix described in section 1 reflects both new equity and debt transfers from parents to affiliates and the subsequent reinvestment of retained earnings. Both types of investments are leveraged with foreign debt. While individual investments will use different financing mixes, the overall financing mix may remain relatively unchanged if the mix of new investment and reinvestment continues to be about the same. ${ }^{2 s}$

To analyze this overall average financing case, the three sources of financing identified in the "leveraged retained earnings case" must be expanded to include

e - the external equity capital provided by the U.S. parent and other U.S. investors

e* - the external equity capital provided by non-U.S. sources

b - the debt supplied by the U.S. parent and other U.S. creditors

Now $e+e^{*}+b+b^{*}+s+s^{*}=1$.

The econometric results of section 3 and 4 imply that each dollar of cross border equity and debt ( $e$ and $b$ in the current notation) reduces domestic investment by one dollar. If we assume also that each dollar of foreign subsidiary retained earnings that is not invested in the affiliate would otherwise be repatriated and would add dollar-for-dollar to domestic investment in the United States, an additional dollar of foreign affiliate capital financed with the observed average mix of financing sources would reduce the U.S. capital stock by $e+b+s<1$ dollars. Once again this is an upper limit because the repatriation of subsidiary retained earnings may not increase domestic investment dollar for dollar.

${ }^{25}$ It would be desirable to compare the composition of financing of U.S. foreign affiliates in the 1989 benchmark survey with the financing composition in earlier studies. 
The analysis of section 1 showed that of the $\$ 1237$ billion of total assets, the external equity finance from U.S. sources was $\$ 203$ billion, the debt from U.S. parents and other U.S. creditors was $\$ 47$ billion, and the share of retained earnings attributable to U.S. parents and other investors was $\$ 226$ billion. In this case, $e+b=0.20$ and $e+b+s=0.38$. If each dollar of retained earnings would otherwise be repatriated and add one dollar to domestic investment, each dollar of foreign affiliate investment financed by this average mix of sources reduces the U.S. capital stock by 0.38 dollars. At the other extreme, if the inflow of repatriated eamings would only displace some other portfolio inflow or induce a portfolio outflow, each dollar of foreign affiliate investment financed by this average mix of sources reduces the U.S. capital stock by only 0.20 dollars.

Although individual investments will use different financing mixes, this overall financing case is probably the best indication of how the financing of the foreign affiliate capital stock evolves. If so, it implies that each dollar of displaced domestic capital in the U.S. adds between $\$ 2.60$ and $\$ 5.00$ to the capital stock of U.S. foreign affiliates.

This relation between foregone domestic investment and the increase in the capital stock of U.S. foreign affiliates is important for assessing the impact of outbound FDI on the national income of the United States. The effect of outbound U.S. foreign direct investment on U.S. national income depends on the rate of retirn earned on such investments, the cost of the foreign capital, and the amount of taxes paid to the foreign government. Although U.S. firms that invest abroad presumably select the allocation of capital that maximizes the present value of the firms' after tax profits, the existence of foreign taxes implies that their decisions will not in general maximize U.S. national income. The firm may be indifferent between paying taxes to 
the U.S. government and a foreign government but only the former remains a part of U.S. national income. An evaluation of whether the outbound U.S. FDI increases or decreases U.S. national income requires balancing the tax losses to foreign governments against the advantage of the increased use of foreign source capital that accompanies foreign direct investment. That analysis is the subject of a separate study (Feldstein, 1994).

Cambridge MA

December 1993

Revised

February 1994 


\section{References}

Baxter, Marianne and Mario Crucini (1993), "Explaining Saving-Investment Correlations," American Economic Review 83:3 pp. $416-36$

Bergsten, C. Fred, Thomas Horst, and Theodore H. Moran (1978), American Multinationals and American Interests, Washington, DC: Brookings Institution.

Blomstrom, Magnus, Robert E. Lipsey, and Ksenia Kulchycky (1988), "U.S. and Swedish Direct Investment and Exports," in Robert E. Baldwin, Ed., Trade Policy Issues and Empirical Analysis, Chicago: University of Chicago Press, pp. 259-297.

Feldstein, Martin (1983), "Domestic Saving and International Capital Movements in the Long Run and the Short Run," European Economic Review.

Feldstein, Martin (1994), "Taxes, Leverage and the National Retum on Foreign Direct Investment, " forthcoming.

Feldstein, Martin and Phillipe Bacchetta (1991), "National Saving and International Investment," in The Economics of Savings, John Shoven and Douglas Bemheim, (eds.), Chicago: University of Chicago Press.

Feldstein, Martin and Charles Horioka (1980), "Domestic Savings and International Capital Flows," The 1970 W.A. Mackintosh Lecture at Queen's University, Economic Journal.

Frankel, Jeffrey (1991), "Quantifying International Capital Mobility in the 1980s," in National Saving and Economic Performance, D. Bernheim and J. Shoven (eds.): Chicago: University of Chicago Press. 
Froot, Kenneth (1993), Foreign Direct Investment Chicago: University of Chicago Press.

Graham, Edward M. and Paul Krugman (1991), Foreign Direct Investment in the United States. Washington, DC: Institute for International Economics.

Hufbauer, Gary C., and F.M. Adler (1968), Overseas Manufacturing Investment and the Balance of Payments, Tax Policy Research Study No. 1, U.S. Treasury Department, Washington, D.C.

Lipsey, Robert (1993) "Outward Direct Investment and the U.S. Economy," in The Effects of International Taxation on Multinational Corporations, M. Feldstein, J. Hines and R.G. Hubbard (eds.) NBER Conference Volume, forthcoming.

Lipsey, Robert and Merle Yahr Weiss (1981), "Foreign Production and Exports in Manufacturing Industries," Review of Economics and Statistics, Vol. LXIII, No. 4, November, pp. 488-494.

Lipsey, Robert and Merle Yahr Weiss (1984), "Foreign Production and Exports of Individual Firms," Review of Economics and Statistics, Vol. 66, No. 2, May, pp. 304-308.

Mussa, Michael and Morris Goldstein (1993), "The Integration of World Capital Markets, " in Changing Capital Markets: Implications for Monetary Policy, 1993 Annual conference of the Kansas City Federal Reserve Bank, (forthcoming).

Severn, Alan (1972), "Investment and Financial Behavior of American Direct Investors in Manufacturing," in Fritz Machlup, Walter Salant, and Loria Tarshis, Eds., The International Mobility and Movement of Capital, New York: National Bureau of Economic Research.

Stevens, Guy and Robert Lipsey (1992) "Interactions between Domestic and Foreign 
Investment, " Journal of International Money and Finance, 11 pp 40-62.

U.S. Department of Commerce, Economics and Statistics Administration, Bureau of Economic Analysis (1992), U. S. Direct Investment Abroad: 1989 Benchmark Survey, Final Results. 


\section{Appendix A}

Table A.1

\begin{tabular}{|c|c|c|c|c|c|c|}
\hline \multicolumn{7}{|c|}{ Decade Averages of Investment, Saving and FDI Ratios: $1970-79$} \\
\hline \multirow[b]{2}{*}{ Country } & \multicolumn{6}{|c|}{ Ratios to GDP } \\
\hline & GDI & GNS & $\begin{array}{l}\text { Outbound } \\
\text { FDI* }^{*}\end{array}$ & $\begin{array}{l}\text { Inbound } \\
\text { FDl }^{*}\end{array}$ & $\begin{array}{c}\text { Outbound } \\
\text { RE }\end{array}$ & $\begin{array}{c}\text { Inbound } \\
\text { RE }\end{array}$ \\
\hline Australia & 0.250 & 0.238 & 0.001 & 0.007 & 0.001 & 0.006 \\
\hline Austria & 0.286 & 0.278 & 0.001 & 0.005 & NA & NA \\
\hline Belgium/Luxembourg & 0.227 & 0.232 & 0.007 & 0.015 & NA & NA \\
\hline Canada & 0.240 & 0.224 & 0.008 & 0.007 & NA & NA \\
\hline Finland & 0.285 & 0.265 & 0.002 & 0.002 & NA & NA \\
\hline France & 0.255 & 0.259 & 0.003 & 0.004 & 0.000 & 0.000 \\
\hline Germany & 0.234 & 0.244 & 0.005 & 0.003 & 0.001 & 0.001 \\
\hline Italy & 0.258 & 0.260 & 0.002 & 0.003 & NA & NA \\
\hline Japan & 0.345 & 0.353 & 0.003 & 0.000 & NA & NA \\
\hline Netherlands & 0.234 & 0.246 & 0.018 & 0.010 & 0.006 & 0.002 \\
\hline New Zealand & 0.260 & 0.217 & 0.001 & 0.008 & 0.001 & 0.008 \\
\hline Spain & 0.266 & 0.251 & 0.001 & 0.006 & NA & NA \\
\hline Sweden & 0.216 & 0.209 & 0.006 & 0.001 & 0.000 & 0.000 \\
\hline United Kingdom & 0.199 & 0.180 & 0.010 & 0.009 & 0.009 & 0.005 \\
\hline United States & 0.194 & 0.197 & 0.003 & 0.001 & 0.005 & 0.001 \\
\hline
\end{tabular}

* Excludes Retained Earnings

NA Not Available 
Table A.2

\begin{tabular}{|c|c|c|c|c|c|c|}
\hline \multicolumn{7}{|c|}{ Decade Averages of Investment, Saving and FDI Ratios: $1980-90$} \\
\hline \multirow[b]{2}{*}{ Country } & \multicolumn{6}{|c|}{ Ratios to GDP } \\
\hline & GDI & GNS & $\begin{array}{l}\text { Outbound } \\
\text { FDI* }\end{array}$ & $\begin{array}{c}\text { Inbound } \\
\text { FDI* }^{*}\end{array}$ & $\begin{array}{c}\text { Outbound } \\
\text { RE }\end{array}$ & $\begin{array}{c}\text { Inbound } \\
\text { RE }\end{array}$ \\
\hline Australia & 0.244 & 0.198 & 0.007 & 0.013 & 0.003 & 0.004 \\
\hline Austria & 0.245 & 0.242 & 0.003 & 0.003 & NA & NA \\
\hline Belgium/Luxembourg & 0.176 & 0.171 & 0.014 & 0.020 & NA & NA \\
\hline Canada & 0.215 & 0.198 & 0.012 & 0.003 & NA & NA \\
\hline Denmark & 0.181 & 0.152 & 0.006 & 0.003 & NA & NA \\
\hline Finland & 0.258 & 0.237 & 0.012 & 0.002 & 0.000 & 0.001 \\
\hline France & 0.209 & 0.204 & 0.010 & 0.006 & 0.000 & 0.000 \\
\hline Germany & 0.206 & 0.227 & 0.009 & 0.003 & 0.001 & 0.000 \\
\hline Italy & 0.225 & 0.216 & 0.004 & 0.003 & NA & NA \\
\hline Japan & 0.300 & 0.321 & 0.007 & 0.000 & NA & NA \\
\hline Netherlands & 0.197 & 0.225 & 0.027 & 0.013 & 0.009 & 0.005 \\
\hline New Zealand & 0.242 & 0.182 & 0.005 & 0.010 & 0.005 & 0.006 \\
\hline Norway & 0.259 & 0.267 & 0.011 & 0.006 & NA & NA \\
\hline Portugal & 0.282 & 0.237 & 0.001 & 0.015 & 0.000 & 0.001 \\
\hline Spain & 0.221 & 0.208 & 0.003 & 0.015 & NA & NA \\
\hline Sweden & 0.188 & 0.169 & 0.020 & 0.004 & 0.005 & 0.001 \\
\hline United Kingdom & 0.176 & 0.166 & 0.015 & 0.012 & 0.012 & 0.006 \\
\hline United States & 0.179 & 0.163 & 0.000 & 0.008 & 0.003 & 0.000 \\
\hline
\end{tabular}

- Excludes Relained Earnings

NA Not Available

APPENDXA.DOC (WordPerfect)

APPENDXA.WK3 (Lotus) 